\title{
ROMANIA | GERMANIA
}

\section{Manuel A. Quirós Rodríguez}

\begin{abstract}
RESUMEN
Este trabajo se centra en la presentación de aspectos históricos, culturales y lingüísticos (principalmente, léxicos) en las relaciones entre cultura latina-románica con la germánica. Entre otras consideraciones, se presentan préstamos linguiísticos del latín a las lenguas germánicas y préstamos del germánico, principalmente del visigótico, al naciente romance castellano. Casi todos los préstamos tomados en consideración se usan en la actualidad.
\end{abstract}

\section{ABSTRACT}

This paper focuses on a historical, cultural and linguistic, above all, lexical, relations between LatinRomance civilization and German.

Among other aspects, linguistic borrowing from Latin to German, and from Visigothic to the incipient romance Spanish are submitted. Almost all borrowings taken in consideration are used at present.

\section{Introducción}

Este artículo está conformado por tres partes esenciales:

I. Algunas influencias del latín sobre el alemán y el inglés.

II. Algunas influencias de los idiomas germánicos sobre las lenguas romances. III. El visigótico y sus influencias sobre el futuro castellano.

Del asentamiento de los pueblos germanos en el antiguo Imperio Romano, resulta el sintagma ROMANIA | GERMANIA. Estos dos conceptos traen inherente toda clase de encuentros, incluso encontronazos, prolongados hasta el siglo XX.

Con la denominación anterior, presento algo de las relaciones recíprocas, tanto históricas como culturales, ante todo léxicas, entabladas entre los pueblos germanos norteños con los románicos sureños. En tales relaciones no está ausente la acción desplegada por Roma y el latín.

El concepto de germanismo, un "superestrato", involucra los idiomas procedentes del Urgermanisch, derivado, a su vez, del indoeuropeo, como el latín y el griego. Ellos son: alemán, inglés, neerlandés (propio de Holanda y Bélgica flamenca), danés, sueco, noruego, islandés y frisón. 
El nombre de germanismo, y no el de "alemanismo", es aplicado, específicamente, para préstamos del alemán. A los préstamos del inglés se les conoce como anglicismos.

\section{Alemania-Germania, Anglia, Britannia}

Es difícil desentrañar la vicisitud lingüística del nombre de Alemania, denominación de una tribu germánica, los alamanes, de donde proceden, en español, Alemania, alemán y Allemagne, allemand, en francés. En latín, es Germania, del cual se tomó, en italiano, Germania y, en inglés, Germany. La etimología latina de Germania ha sido muy discutida: algunos dicen que se deriva de Heer, ejército, y Mann, hombre: hombres del ejército. Los nombres de Germania-germani aparecen en la Germania de Tácito. El italiano usa el gentilicio tedesco palabra que procede del latín teuto, teutonis $>$ Deutsch, gentilicio de otra tribu germánica con el significado de pueblo (theod). De modo que teuto, pl. teutones, significa "el pueblo por antonomasia", en confrontación con otros pueblos, y de Deutsch se deriva el nombre de Deutschland, Alemania. Del mismo étimo es Dieta, asamblea del Sacro Imperio Romano-Germánico.

Con la constitución del imperio de los francos, la más importante de las etnias germánicas, principalmente con Carlomagno, se formó el Imperio Romano-Germánico de las Naciones, continuado por la casa real de los otones, con sede en Alemania pero con miras y apetencias sobre Roma.

Para dirimir el asunto sobre el idioma de la predicación, en una asamblea eclesiástica del siglo IX se estipuló el uso de la lengua popular en la predicación evangélica, en vez del latín, y entonces aparecieron los términos de rustica romana lingua, para el romance (francés antiguo) y de theudisca, para el germánico, con lo cual se indica que el término romance nació en un medio germánico como vecindad-contraposición: allí, entre los ríos Escalda y el Mosela, en contacto con poblaciones romanas, conocidas por los germanos con el nombre de walhik $>$ welsch $>$ volcae, tribuna celta despreciada por los antiguos romanos, a la cual se le debe el significado de "extranjero", nace la conciencia "nacional", que ha causado tantos problemas bélicos entre dos etnias: los románicos < romanos, y los germánicos, con el nombre de theudisc < teuto $>$ Deutsch (teutón).

Inglaterra, Anglia en latín, significa el país de los anglos, otra etnia germánica; su pseudónimo, Bretaña, se deriva de Britannia, forma latinizada, procedente de bretón, etnia celta. De los sajones, procedentes de Sajonia, Alemania, se usa el sintagma anglo-sajón.

\section{Origen, denominación étnica y asentamiento de los germanos}

Los germanos eran etnias que habitaban, y habitan todavía, regiones del norte europeo. Como manifesté, su origen es indoeuropeo y sus lenguas, indoeuropeas; genéticamente, pues, parientes del latín y del griego.

Sobre el origen étnico de los pueblos germanos reina mucha inseguridad e incertidumbre, pero se cree que su región nativa haya sido el sur de Escandinavia y el norte de Alemania. Tal inseguridad e incertidumbre se debe, ante todo, a la falta de documentos escritos, no tan prolíficos como los de los griegos y los romanos. 
Tácito (c. 55 - 120+) historiador romano, iniciando no más su Germania, esboza, de modo general, el sitio de origen y estadía de los germanos:

\begin{abstract}
Germania omnis a Gallis Raetisque et Pannoniis Rheno et Danuvio fluminibus, a Sarmatis Dacisque mutuo metu aut montibus separatur; cetera Oceanus ambit, latos sinus et insularum inmensa spatia complectens, nuper cognitis quibusdam gentibus ac regibus, quos bellum aperuit. Rhenus Raeticarum Alpium inaccesso ac praecipiti vertice ortus, modico flexu in occidentem versus septentrionali Oceano miscetur. Danuvius molli et clementer edito montis Abnobae iugo effusus, pluris populos adit, donec in Ponticum mare sex meatibus erumpat; septimum os paludibus hauritur.
\end{abstract}

\begin{abstract}
Toda Germania está limitada de los galos, retios y húngaros por los ríos Rin y Danubio, y de los sármatas (rusos actuales) y dacios por un mutuo temor o por montañas; los territorios restantes están circundados por el Océano, el cual rodea amplias sinuosidades e inmensos espacios insulares, hasta poco ha conocidos por ciertas gentes y reyes, a quienes se los dio a conocer la guerra...

(La segunda parte de este primer párrafo describe el origen y el curso del Rin y del Danubio hasta sus desembocaduras).
\end{abstract}

A finales del -I siglo, en época del cónsul Mario, se tienen noticias de los cimbrios y teutones, los primeros que aparecen en la historia germana, ya ocasionándoles problemas a los romanos y tratando de pasar el Limes Romanus. Como contrapartida, a finales del mismo siglo, comienzan a penetrar en el idioma alemán palabras de origen latino debido a las relaciones de vecindad con el Imperium Romanum, así como palabras germanas en el latín vulgar.

De mediados del siglo anterior, existen datos registrados por escritores romanos, aunque los germanos todavía no eran muy bien conocidos. Lo narrado por Julio César en el $\mathrm{Be}$ llum Gallicum quizás no proceda de este historiador.

En época del Imperium Romanum, los germani habitaban la Germania Superior y la Germania Inferior: un territorio al oeste del Rin y al sur del Danubio, por donde pasaba, precisamente, el Limes Romanus, la prolongada frontera con el imperio. Esta segunda Germania estaba constituida por las provincias renanas, parte de Holanda, Baviera, el Tirol y Suiza.

En un cierto momento, a los romanos no les quedó otra elección que aceptar a los germanos dentro de partes de sus fronteras. Con Cayo Julio César, se dio un alistamiento en el ejército romano. Algunos germanos obtuvieron la libertad y actuaron de mercenarios

A partir del siglo III+, los germanos se habían puesto en movimiento hacia el Occidente del Imperio Romano: los alamanes conquistan los Campos Decumates (Agri Decumates) entre el Rin y el Danubio; otros caen en el Limes Romanus, e incluso, en Italia, de donde son expulsados por Claudio II y por Aureliano, quien construyó la muralla de Roma, que la protegió hasta el 410+. En 375+, olas de germanos invaden todo el Imperio Romano de Occidente con consecuencias negativas para el Imperio Romano de Oriente.

En el mismo siglo, había ya un número preponderante de soldados germanos en las filas romanas. En el IV+, muchos se constituyeron en súbditos del Imperium Romanum. Se debe esperar hasta este siglo para que aparezca el primer texto en una lengua germánica antigua: la traducción de la Biblia al visigótico por el obispo arriano, Úlfilas (*Wulf-il-a, lobezno, presumiblemente muerto en el 383+); tal texto ha llegado hasta el presente en el Codex Argenteus de Úpsala y en fragmentos principalmente escritos en monasterios de la Italia norteña. Entre tanto, ya había sido escrita casi toda la literatura de la Roma antigua. Además de lo escrito por Tácito, uno de los mejores conocimientos sobre los germanos ha sido obtenido de excavaciones y noticias de autores griegos y romanos, sobre todo del escritor Procopio, lo cual es de mayor valía para la época de las invasiones. En 551+, el escritor alano, Jordanes, narra sobre el Origen y hechos de los Godos. 


\section{Los germanos según Cornelio Tácito}

El cuadro más completo de los pueblos germanos, aunque de segunda mano, es y está proporcionado en la Germania de Tácito: su ser, su origen étnico y su configuración corporal: color de sus ojos, cabellos y piel; características y costumbres; incluso, "pureza" de éstas (como opuestas a la malsana vida de los romanos contemporáneos de Tácito); alta estima de la mujer, adquisición de tierras e instrumentos de labranza; armas, manera de guerrear y su vida en épocas de paz; religión, incluso sepelios y culto a los difuntos; oráculos, asambleas del pueblo y asuntos de derecho; habitación, vida matrimonial, hasta en caso de rompimiento; educación de los hijos y niños, recepción de huéspedes, comidas y bebidas, juegos y diversiones: los de dados y la danza de la espada, entre otros; situación de los esclavos y su libertad.

Por ser, como dije, "de segunda mano", se debe tener cuidado al juzgar los datos de Tácito, aunque los obtenidos de excavaciones arqueológicas concuerdan con el historiador.

\section{En 476+, golpe a Roma, pero...}

\section{¡Roma romaniza, latiniza y cristianiza en latín!}

Los latinismos en las lenguas germánicas se han debido a toda clase de contactos del mundo latino con el mundo germánico y, más adelante, entre la Germania y la Romania: han penetrado en ellas por las mismas razones y mediante las mismas vías de como lo hecho en las lenguas romances. Mas un latinismo es mucho más fácil de detectar en los idiomas germánicos, pues éstos poseen menor parecido con el latín, motivo por el cual el inglés y el alemán tuvieron una escritura, incluso literaria, más precoz que en los romances, cuyos pueblos se servían, en mayor medida, de la antigua lengua de Roma.

Los pueblos germánicos, principalmente de Alemania y Austria, se han puesto en contacto, por el motivo que fuese, con el mundo latino desde la época imperial mediante el proceso de la romanización-latinización y de los enfrentamientos bélicos.

El año 476, marca un tremendo golpe contra la civilización: la Roma del reyezuelo Rómulo Augústulo cae en poder de Alarico, rey de los Hérulos. Tan importante es esta fecha que es considerada por algunos como el inicio de la Edad Media con el consiguiente fin de la Edad Antigua.

Sobre los despojos del Imperio Romano, ya destronada Roma, se asientan los reinos germanos, siempre desunidos entre sí, a los cuales Teodorico pretendió unificar, pero sin éxito alguno.

Sin embargo, la desaparición del Imperio Romano de Occidente no implica, necesariamente, el aniquilamiento de la cultura latina ni del latín; éste siguió siendo empleado como lengua docente, literaria, jurídica, notarial y eclesiástica; eclesiástica, pues una institución sustituye a otra institución: la Roma pagana le cede el lugar a la Roma cristiana; la Roma imperial le cede su puesto a la Roma papal.

La Edad Media no rompe con mucho de lo positivo heredado por la tradición clásica de la Edad Antigua. ¡Menos con el idioma! Por eso, el latín se siguió usando en tal edad, desde el principio hasta el final; y literatura en latín se siguió escribiendo, en casi toda Europa, hasta más hacia acá del Humanismo-Renacimiento. De inmediato, luego que el latín vulgar se 
hubo transformado, por ahí del siglo IX, en romance(s), la primera reacción culta del latín es efectuada por obispos, quienes toman en sus manos la vida administrativa de las ciudades y parroquias, centro de la vida comunal, y el latín empleado por ellos se constituye en un elemento nuevo de educación y cultura, aunque fuera sólo escuchándolo, principalmente, cuando la gente asistía a las ceremonias del culto romano.

\section{Asentamiento de las principales tribus germanas}

\begin{tabular}{l} 
Alamanes: \\
\hline Alanos: \\
Burgundios: \\
Francos \\
- Ripuarios: \\
- Salios: \\
Gépidos: \\
Longobardos: \\
Ostrogodos: \\
Sajones: \\
Suevos: \\
Turingios: \\
Vándalos:
\end{tabular}

Visigodos: cursos altos del Rin y del Danubio. estribaciones del Cáucaso. Hacia Lusitania y Carthaginensis.

sur de los francos ripuarios.

norte de Brabante.

resto de la Gallia: riberas septentrionales del Rin. valle del río Theiss.

entre el Elba y el Oder; luego, a Lombardía. norte del mar Negro; luego, Italia, 568. costas del mar del Norte. Luego, a Inglaterra. Ribereños del Elba y el Oder; luego, Galicia. Alto Elba.

Entre el Vístula y el Oder; luego, sur de España; después, hacia Norte de África. La Iulia Traducta fue llamada Portus Vandalusius > Vandalucía $>$ Andalucía.

Bajo Danubio, lado izquierdo, sur de Gallia y, luego, a Hispania.

La más importante tribu germana fue la de los francos, como mencioné, pues logró sobreponerse, aunque mezclada con la cultura latina, y conformar, de este modo, una comunidad románico-germánica. También el reino de los ostrogodos, situado en Italia, cae en su poder. El nuevo césar, Carlomagno, reunió bajo su cetro muchos territorios occidentales del antiguo Imperio Romano. Como el reino franco tuvo dificultades para ser reconocido por el Imperio Romano de Oriente, Carlomagno se hizo coronar (si no es que él mismo se colocara la corona) emperador por el Papa un 24 de diciembre del 800, con lo cual se salvó de milagro la cultura clásica antigua, dada la enorme visión del emperador, quien, entre otros aspectos, supo aprovechar la misión cultural de monjes benedictinos, principalmente, en la trascripción de textos. 


\section{7. ¿Poseían los germanos conocimiento del latín?}

Desde el inicio de la Edad Media, el contacto de los germanos con el mundo latino (el que los civilizó, les dio su cultura y los cristianizó) se debió a los misioneros enviados desde Roma a cristianizar; y cristianizar significaba civilizar. Tanto es así que muchos de ellos iban cargados de códices. Por tal motivo, los países que conforman el mundo germánico, incluyendo Inglaterra, conservan mucho de la cultura latina y son de tradición cristiana; incluso, antes de la Reforma Luterana, eran católicos que, como tales, giraban en torno a Roma tanto para asuntos religiosos como para políticos. Así, por ejemplo, Carlomagno era un franco, y el Sacro Imperio Romano-Germano tuvo un vínculo muy estrecho con la Roma papal.

La situación del idioma alemán con respecto al latín no deja de ser interesante, pues se trata de una lengua germana que ha tomado prestadas del latín muchas palabras, tanto cultismos como latinismos en varios campos. Algunas de esas palabras se han acomodado a la idiosincrasia del alemán, la lengua germánica que ha tenido más contacto directo con los idiomas romances, principalmente, con el francés, por razones raciales, históricas y fronterizas, en especial en la región de Renania.

El latinismo en una lengua germánica presupone la adopción de determinada palabra directamente del latín, tal y como lo es en este idioma. Pero si una palabra, aunque sea latina, se deriva de alguno de los idiomas romances, será, según el caso, hispanismo, italianismo, galicismo, lusitanismo, catalanismo..., y en estos mismos idiomas podrá ser, además, cultismo, semicultismo o voz patrimonial.

Naturalmente, no todos los germanos conocían el latín; pero algunos sí, por las siguientes razones:

1. En el centro del valle del Rin, se formó una coiné latina debido a una fusión entre germanos y romanos.

2. En las filas del ejército romano había germanos.

3. Según César, los comerciantes romanos eran entendidos por ubios y suevos.

4. Según Tácito, Ariovisto entendía latín.

5. Según Plinio el Joven, los edictos de Trajano eran entendidos por germanos.

6. Carlo Tagliavini, en Orígenes (383), manifiesta que las clases más altas de los germanos sabían latín, pero que muy raras veces los romanos se tomaban la molestia de aprender las lenguas de los pueblos germánicos sometidos.

\section{Influencias del latín sobre el germano}

Antes del 450, en cierto momento, por razones de prestigio, comenzó a tener influencia el latín, el cual se encuentra en las siguientes palabras germanas de origen latino: 


$\begin{array}{lll}\text { Latín } & \text { Germano } & \text { Traducción } \\ \text { acetum } & \text { al. Essig } & \text { vinagre } \\ \text { caesar } & \text { al. Kaiser } & \text { césar } \\ \text { calicem } & \text { al. Kelch } & \text { cáliz, copa, vaso } \\ \text { cellarium } & \text { al. Keller } & \text { cueva, bodega } \\ \text { caupo, -onis } & \text { al. Kauf } & \text { tabernero } \\ \text { cista } & \text { al. Kiste } & \text { cesta } \\ \text { *moneta } & \text { al. Münze; ingl. money } & \text { dinero, moneda } \\ \text { mustum } & \text { al. Most } & \text { mosto (vino nuevo) } \\ \text { pilum } & \text { al. Pfeil } & \text { jabalina, dardo } \\ \text { pondus, -eris } & \text { al. Pfund, got. pund, } & \text { pesa, peso, libra } \\ & \text { ingl. pound } & \\ \text { (viarum) strata }<\text { stratum, capa } & \text { al. Strasse, } \text { ing. } \text { street, } & \text { calles pavimentadas } \\ & \text { hol. } \text { straat } & \end{array}$

*moneta, -ae [monere]. Sobrenombre de la diosa Juno, correspondiente a su advocación como "consejera, avisadora", pues los graznidos de los gansos del Capitolio, en donde se encontraba su templo, dentro del cual se acuñaba la "moneda", despertaron a los soldados, los cuales resistieron el golpe de los galos.

\section{Toponimia}

augustus

colonia (Agrippina)

confluentes

monachus $<$ HovaXo"
Ausgsburg

Köln

Koblenz

München
Augsburgo

Colonia

Coblenza

Munich

\section{Documentación de latinismos en autores latinos}

Sobre este punto, E. Gamillscheg, en Germanismos (1967: 79), expresa que el léxico de origen germánico atestiguado hasta el 400+ en escritores latinos o en inscripciones es muy raro y no desempeña ningún papel de importancia en el vocabulario de la lengua española. Entre tales pocas palabras, se encuentran las siguientes:

$\begin{array}{lll}\begin{array}{ll}\text { germano } \\ \text { alce }\end{array} & \text { latín } & \text { autor } \\ \text { burgs } & \text { César } \\ \text { melca } & \text { melca } * & \text { Vegecio } \\ \text { framea, lanza } & \text { framea } & \text { Apicio } \\ \text { ganta, oca } & \text { ganta } & \text { Tácito } \\ \text { sapo (al. Seife, ingl. soap) } & \text { sapo, -onis (jabón) } & \text { Plinio } \\ \text { urus, buey salvaje } & & \text { Plinio } \\ & & \text { César }\end{array}$

* castellum parvum quem burgum vocant. Cita aportada por Menéndez Pidal, quien añade esto: Debió haber existido cruce de género gramatical y de significado entre el germá-

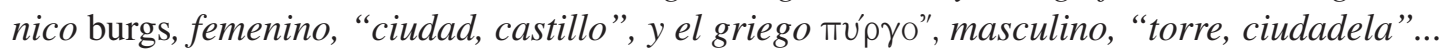




\section{Otros ejemplos}

Kampf < campus, Wall < vallum, Pfahl < palus, Meile $<$ milia (passuum), Kerker $<$ carcer, Markt < mercatum, Karren < carrus, pflanzen < plantare, Maur $<$ murum, Ziegel $<$ tegula, Pforte < porta, Spiegel < speculum, schreiben $<$ scribere, tinte $<$ (aqua) tincta, Brief $<$ brevis (libellus), Meister $<$ magister, Vogt $<$ advocatus, Propst $<$ praepositus, Käse $<$ caseus, Pfalz $<$ palatium, Frucht $<$ fructum, Pferd $<$ paraveredum, Weile $<$ villarium, Meier $<$ maior (domus), Kirsche $<$ ceresus, Pflaume $<$ prunis, Pfirsisch $<$ persicum (malus) periscus, Schüssel $<$ scutella, Birne < pirum, Kohl < caulis, Zwiebel < cepulla, Wein $<$ vinum.

En alemán, los días de la semana son traducciones de las respectivas formas latinas, pues los dioses romanos fueron sustituidos por dioses germanos, inclusive antes de la penetración del cristianismo en tierras norteñas:

\begin{tabular}{|lll|}
\hline Sonntag & $=$ & dies Solis (Sol) \\
Montag & $=$ & dies Lunae (Luna) \\
Dienstag < Thingsus & $=$ & dies Martis (Marte) \\
Wednesday (en inglés) $<$ Wodan & $=$ & dies Mercurii (Mercurio) \\
Donnerstag < Donar & $=$ & dies Iovis (Júpiter) \\
Fria & $=$ & dies Veneris (Venus) \\
\hline
\end{tabular}

Además, todos los nombres de los meses, tanto en inglés como en alemán, y, probablemente, en las restantes lenguas germánicas, son de origen latino; en alemán: Januar, Februar, März, April, Mai, Juni, Juli, August, September, Oktober, November, Dezember.

\section{Contribución del latín medieval}

El cristianismo se expandió primero por Grecia y luego pasó a Roma. A partir de aquí, lo hizo por las demás regiones del Antiguo Imperio Romano. De esta forma, Alemania e Inglaterra han recibido una enorme influencia civilizadora del mundo latino, gracias también a la Roma cristiana, en cuya actividad iba también inherente el latín. Una vez civilizados y cristianizados, los germanos desempeñaron, junto con los pueblos románicos, un papel de primer orden en la cultura occidental.

En el siglo VI, tuvo lugar una influencia del latín eclesiástico en Renania y en Alemania del sur. En el VII, Inglaterra se convirtió al cristianismo, lo cual implicaba el uso del latín. En el VIII, Germania Occidental se convirtió, casi toda, a tal religión y se adoptaron, tanto en alemán como en inglés, términos griegos y latinos. Pero no se debe olvidar la desunión relativa, a partir del Renacimiento, de los vínculos con la Roma católica debido a la Reforma.

La importancia del latín es retratada por Helmut Lüdtke, 1974, cuando, casi al finalizar su libro Geschichte des romanischen Wortschatzes, Historia del léxico románico, Funciones del latín: lengua de cultura y lengua ritual, manifiesta que la reforma cultural emprendida por Carlomagno con la desaparición del principio de la identidad de palabras entre lengua culta y lengua espontánea cambió poco, al principio, las funciones comunicativas de los dos idiomas (se trata del latín y del romance). Al igual que antes, la lengua culta (latín) se quedó 
con el monopolio en el dominio tanto de la cultura como de lo ritual, mientras que la lengua espontánea (lingua romana rustica = romance) era un idioma de conversación. La reforma carolingia fue una innovación lingüística decisiva y una toma de conciencia del romance en confrontación con el latín. Con ella, la mayor parte de la Europa románica se adaptó a la situación existente: la coexistencia de una lengua de cultura, válida en un ámbito suprarregional, y de una lengua popular, con una validez regional.

El Cristianismo romano contribuyó a la expansión del latín, incluso allende los confines del Imperium Romanum por tierras norteñas, pues comenzó a ser enseñado en las escuelas y en los recién fundados monasterios, en cuyos scriptoria se realizó una imprescindible labor filológica, de lo cual da pruebas fehacientes el libro Copistas y filólogos escrito por Reynolds-Wilson. En tales regiones, hasta que sus idiomas no hubiesen alcanzado la suficiente madurez gramatical y literaria, la enseñanza se impartía en tal idioma, por lo cual, una inmensa cantidad de libros se escribieron en él. Todo esto llevó a que, por ejemplo, el inglés y el alemán se apropiaran de terminología científica grecolatina; además, los libros sagrados del cristianismo se tradujeron del latín a ambas lenguas. De este modo, la traducción ejerció una poderosa influencia en la creación, verbi gratia, de calcos: Heiliger Geist traduce a Spiritus Sanctus, Bamherzankeit traduce a misericordia; Gnade traduce a gratia.

Los colonizadores cristianos hicieron penetrar su religión por el Rin o por el Danubio. Es más: en la ciudad de Trier < Treveris < tres viros, se dio una continuidad romana.

Algunas palabras alemanas latinas de la esfera cristiana son: Kreuz $<$ crucem, Zelle $<$ cella, Kapelle < capella, Kloster $<$ claustrum, Münster $<$ monasterium, Messe $<$ missa, sauber $<$ sobrium, segnen $<$ signare, opfer $<$ offerre, predigen $<$ praedicare, Feier $<$ feria, Keusch $<$ conscius; y dos préstamos de formación son: Eindruck < impressio y Ausdruck < expressio.

\section{Algunos latinismos en alemán y en inglés modernos}

\subsection{En alemán}

Para no limitarme, única y exclusivamente, a aspectos antiguos sobre las relaciones latín-alemán I inglés, me centro en algunos latinismos modernos, sin tomar en cuenta cultismos en tales idiomas.

Por ser el latín un idioma internacional que ha actuado y actúa, junto con el griego, como lengua de adstrato cultural sobre las lenguas modernas aunque éstas no sean romances, no desaprovecho esta ocasión para registrar, sin ningún comentario, algunos latinismos que se encuentran en las dos lenguas germánicas, objeto de mi exposición.

Por ahora, presento, en orden alfabético, algunos latinismos en idioma alemán. Escribo el inicio de la palabra con letra minúscula, a sabiendas de que en alemán todos los sustantivos inician con mayúscula. Muchos de los términos latinos los copié de libros; otros, los escuché en la Deutsche Welle.

Santiago Segura Munguía (1985: 1078-84) presenta, en columnas de cuatro, con letra menuda, un índice de palabras alemanas procedentes del latín; casi todas estas palabras están adaptadas al idioma alemán, como Dom < domus (casa), catedral. Algunas de ellas, proceden del latín vía algún idioma romance, como allegro, del italiano, o chanson, del francés; 
roman < romanice a través del francés roman; otras no son latinas, sino griegas, como Bischof, obispo, o Schule, escuela, y otras son de origen hebreo, merced al cristianismo. El parecido de Vater con pater se debe a que ambas palabras vienen del indoeuropeo. Villa tal vez proceda del latín, tal vez del italiano. Pero existen, es natural, las palabras autóctonas de origen germano como Garten < gart (voz francona), aunque relacionada con la latina hortus.

Los ejemplos tomados en consideración, extraídos, única y exclusivamente, del campo académico universitario, constituyen una muestra de la influencia del latín en alemán. Como tales palabras son muy parecidas a las respectivas del español, me ahorro la traducción:

\begin{abstract}
Alma mater, alumnus (pl. alumni), auditorium, campus, cantor, codex, collegium, collegium academicum, collegium musicum, concentus musicus, kolloquium, kompendium, konservatorium, doctor, doctor honoris causa, doctor iuris, doctor medicinae, emeritus, examen, exerzitium, gaudeamus igitur!, laudatio, magister, magister artium, mensa numerus clausus, pensum, professor, rigurosum, schola cantorum, stipendium, studium, studium generale, venia legendi, verbum, volumen...
\end{abstract}

\title{
10.1. En inglés
}

El inglés es de origen anglosajón, pero con una enorme influencia del latín y del francés: Inglaterra tuvo cierto contacto de orden militar con los romanos; incluso, Julio César estuvo en el sur. Más tarde, llegaron misioneros sureños del Continente a evangelizar y crearon un núcleo bastante fuerte de cristianización, lo cual significó también, indirectamente, como en el caso de Alemania, romanización-latinización. Incluso, sin tal núcleo es inconcebible el Renacimiento Carolingio, el cual partió de monasterios irlandeses e ingleses.

En la Edad Media, Inglaterra siguió girando en torno a la órbita latinorrománica, sobre todo por sus relaciones con Francia y las pretensiones políticas de las diversas casas dinásticas. La enseñanza escolar era en latín y, en Oxford y Cambridge, sus dos baluartes intelectuales, también se enseñaba en latín. Particularmente, Oxford ha sido un centro importante de estudios clásicos. A factores más que todo culturales, se debe la penetración de los latinismos en inglés, penetración que no ha sido impedida en aquel país del Nuevo Mundo que se desató de sus lazos políticos: los Estados Unidos de América. Ahí, en algunas de las más prestigiosas universidades, se enseñan latín y griego, se publican algunas revistas clásicas, se investiga en lo clásico y aparecen muchos latinismos, por ejemplo, en lemas de universidades y colegios, e incluso, de algunas ciudades y estados.

Inglaterra siguió muy unida al cristianismo de Roma hasta la época de Enrique VIII, durante el Renacimiento.

Es inmensa la cantidad de cultismos y latinismos existentes en el idioma inglés, el cual, en algunos casos, ha servido como puente para la penetración de latinismos en otros idiomas modernos, dada la internacionalidad de la lengua inglesa. Particularmente, el derecho es muy rico en préstamos latinos.

Aquí sólo recojo una mínima cantidad de latinismos. Se puede notar que muchos poseen una gran similitud con el idioma español, si no es que también existan en éste. Varios han sido tomados por mí mediante la vista, y otros, por el oído: los canales de televisión.

Regresando al diccionario de Segura Munguía, éste recoge latinismos en inglés de la página 1066 a 1077. Pero como antes había logrado obtener varios latinismos por otras fuentes, paso por alto tal diccionario. La muestra presentada es del todo aleatoria. 
A posteriori, a priori, actor, ad hoc, addenda, agenda, album, alma mater, alumni, audio, auditor, auditorium, axis, campus, cantor, codex, consortium, continuum, curator, curriculum, data, deficit, doctor, emeritus, et alii, explicit, facsimile, factor, formula, genius, iunior, lapsus, maximum, media, minimum, minister, optimum, per capita, persona non grata, plenum, plus, podium, professor, propaganda, prospectus, quorum, ratio, scriptorium, senator, senior, series, species, statu quo, video...

\section{Penetración de germanismos en latín $\rightarrow$ lenguas romances}

Seguidamente, le doy vuelta a la medalla para mostrar algunos préstamos del germánico antiguo en la Romania, sobre todo, en Hispania, por vía visigótica.

Los idiomas germánicos influenciaron el latín y el naciente romance, pero, como vimos, también fueron ampliamente influenciados por el diasistema del latín, incluso, mediante el cristianismo y desde la Edad Media hasta la época actual. A pesar de las invasiones de los pueblos "bárbaros", en muchas zonas ocupadas por éstos, triunfó el latín y el romance, pues no pudieron ser desplazados por varios motivos: la tradición clásica y el antiguo prestigio civilizador de Roma y el latín. Se dio, más bien, el proceso contrario: en muchos casos, los germanos se romanizan, cristianizan y aceptan el latín como idioma de cultura y el respectivo romance como idioma de la vida diaria, como sucedió con los longobardos-ostrogodos, francos y visigodos; pero, a pesar de la desaparición de sus lenguas, éstas dejan reliquias en latín-romance en calidad de préstamos de superestrato, pues, como escribe Walter von Wartburg: en estos casos, la lengua desaparecida puede teñir con algunos rasgos fónicos, léxicos y gramaticales a la lengua persistente.

\section{Situación del latín cuando se situaron los germanos}

Cuando las tribus germánicas, mediante las Völkerwanderungen, se pusieron en contacto con el Imperium Romanum, el latín vulgar era aún bastante unitario y ya había asimilado la mayor parte de los préstamos de sustrato, aunque en cada sitio el latín poseía ciertas particularidades de las lenguas auctóctonas, de modo que se puede hablar de un latín vulgar de Hispania, Gallia, Italia..., sin excluir los arcaísmos y germanismos propios de cada región. A pesar de la relativa unidad latina, ya están en ciernes las diferencias de las futuras variedades románicas.

La llegada de las etnias germánicas a Roma-Romania es conocida con el germanismo de Völkerwanderungen, transmigración, emigración, migración de los pueblos. Por lo general, luego de las invasiones germánicas, como con las árabes, el latín y el romance en potencia logran sobrevivir; por eso, los germanismos son reliquias o préstamos de superestrato.

La penetración germana ha seguido diversos pasos en distintas épocas, a veces difíciles de determinar:

1. Hacia la coiné latina. Por eso son germanismos comunes en todas las lenguas romances, que, inclusive, han sustituido la correspondiente palabra del latín vulgar. Al respecto, en lo tocante a los germanismos del idioma español, E. Gamillscheg, en: Germanismos (1967: p. 79) escribe lo siguiente: 
Los elementos germánicos que sobreviven en la lengua española están, en su menor parte, tomados directamente de un idioma germánico. En la mayoría de los casos estos elementos provienen o directamente del latín vulgar o de otra lengua románica, en primer lugar, del francés...

2. Según la imposición territorial. Se trata de germanismos procedentes de una respectiva tribu germánica: francos (500 voces) + burgundios (50) $\rightarrow$ Gallia. Visigodos (13) $\rightarrow$ Hispania. Longobardos (300 voces) y Ostrogodos (60 voces) $\rightarrow$ Italia (Proporciones según Gamillscheg).

\section{A través del francés o del occitano $\rightarrow$ toda la Romania}

Así pues, los préstamos pueden ser comunes a todas las lenguas procedentes del latín, en cuyo caso han sido difundidos por el latín vulgar. Otros germanismos son propios para cada lengua romance: el francón y el burgundio, para el francés; el longobardo y el ostrogodo, para el italiano; y el visigótico, para las lenguas romances de la Hispania.

Los fenómenos fonético-fonológicos, no tomados en cuenta en esta elaboración, se adaptan y amoldan, muchas veces, a la idiosincrasia de la lengua receptora de acuerdo con su época de aceptación y los aspectos morfológicos y sintácticos, tampoco tomados en cuenta, son de mucho menor valía.

Algunos germanismos, los de primera época, del siglo I al IV+, penetran mediante el latín vulgar y son comunes a las lenguas romances, excepto el rumano. Otros son del fráncico o francón y pasan mediante el francés y el occitano; los del visigótico afectan las lenguas iberorrománicas.

En la presente lista de germanismos, no ofrezco ninguna distinción entre las dos primeras procedencias.

En idioma español, los germanismos, no muy numerosos, aunque sí bastante empleados, abarcan varias esferas: prácticas, diplomáticas, jurídicas y afectivas; destacan los vocablos relacionados con distintas actividades y algunos adjetivos relacionados con nombres de colores:

Aspectos afectivos: afán, ardido, escarnir $>$ escarnecer, gana, gasajo $>$ agasajo $<*$ gasali, compañía (al. Geselle, compañero), orgullo, garbo.

Aspectos jurídicos: alodio, bienes patrimoniales; ban > lat. med. bannum $>$ bando $>$ banda > bandido; francón fehu, ganado, > lat. med. fevu $>$ fr. fief $>$ feudo.

Aspectos diplomáticos vs. bélicos: albergue, antbahti > embajada, arenga, botín, burgo, dardo, embajada, espía, flecha, guarecer, hacha, werra > guerra (que, en las lenguas romances sustituye a bellum), heraldo, robar, sitio (¿o del lat. situm x asedio $<$ obsidium, o de sitiar, sentar, como adaptación occitana del bajo latín situare, 'situar'? - Corominas-) tregua, yelmo.

Relación con animales y equitación: brida, arenque, espuela, estribo, ganado < ganar, hato, marta, tejón, pata (palabra sueva).

Prendas para vestir y para el aseo: falda, fieltro, guante, huesa, bota alta (al. Hosen), pantalones, cofia, jabón, *raupa, botín, ropa, tualla.

Aspectos agrícolas: estaca, jardín (al. Garten, ing. Garden), parra.

Adjetivos: blank $>$ blanco, bruno, frisk $>$ fresco, gris, riks $>$ rico, el calco: * ga hlaib (calco) < ga- y hlaifs (ingl. loaf, hogaza), traducido en latín por cum panem > cumpanionem 
I cumpanarium, compañero, con quien se comparte el pan, y que desterró la forma latina de sodalis, -is, amigo, camarada, compañero.

Aspectos varios: adobar, arpa, banco, barón I varón, botar (tirar, arrojar), bramar, brote, buque, esmalte, esquina, estandarte, moho, rueca, sacar, raspar.

Léxico que inicia con $\boldsymbol{g} \boldsymbol{u}>\boldsymbol{w}$ : guadaña, guarda y sus derivados, wissa $>$ guisa, manera, forma, modo (al. Weise, ingl. wise.), sopa.

\section{Palabras híbridas}

Están conformadas por cruces como las preposiciones latinas ex, de y la voz germánica *magan para obtener desmarrido, desmayar.

\section{Germanismos antroponímicos}

Incluso en la actualidad, muchas personas llevan nombres de origen germánico. Normalmente, los nombres germánicos están expresados por dos partes; por ejemplo, el nombre de Ludhuvigs, que aparece, junto con Karlo, Carlos y Ludher, Lutero, Lotario, en los Juramentos de Estrasburgo, y que en alemán moderno es Ludwig, Ludovico o Luis. El nombre es Hlutowigh < hluto, ilustre, y wigh < wiga, combate: ilustre en el combate, como el dios Marte, como manifiesta Ermoldo le Noir en su poema sobre Luis el Piadoso: nempe sonat "Hluto"praeclarum, "Wigh” quoque Mars est.

Entre los más comunes en el campo femenino, están:

Adelaida (en al. Adelheit, nobleza); un derivado, Adela; Blanca, Clotilde, Elvira, Gisela, Matilde.

Existen muchos más en la esfera masculina, además de los tres antes nombrados, como:

Alfredo = todo pacífico (en al. all, todo, y Friede, paz); Bernardo, Eduardo, Enrique (en al. Heinrich < Heimat, casa y reich); Federico (en al. Friedrich > Friede, paz), Heriberto, Gerardo, Godofredo, Guillermo (en al. Willhelm), Luis, Manfredo, Orlando, Ricardo, Rodolfo, Rolando.

\section{Los visigodos y el latín-romance hispánico}

También la Península Ibérica fue "visitada" por germanos: alanos, vándalos, suevos, y, sobre todo, por visigodos (godos del oeste), quienes vencieron a los anteriores, además de expulsar a los bizantinos en 549+. Los suevos fueron arrastrados por la corriente visigoda hacia Galicia y los alanos, hacia Lusitania. Los vándalos, que le dieron el nombre a Vandalucía $>$ Andalucía, fueron despachados hacia África en el 429, y luego sometidos por los bizantinos, quienes andaban tratando de restablecer el ya aniquilado Imperiuum Romanum occidental.

En el lapso del 411/415 al 711, se enmarca la estadía de los visigodos en Hispania, cuyo reino fue implantado por el rey Leovigildo (568-586), quien fijó la sede central en Toledo.

El caso de los visigodos en Hispania como el de los francos en Frantia y el de los longobardos y ostrogodos en Italia, es un ejemplo de la admiración y el respeto de los antiguos germanos por lo latino, que los llevó a aceptar y a fundirse con sus vencidos; por eso, francos y visigodos, longobardos y ostrogodos abandonan, en mucho, su identidad: parte de 
sus costumbres, su religión y el respectivo dialecto de origen germánico, mas tiñen las respectivas lenguas romances de algunos germanismos.

Como sucedió con las demás etnias germánicas, cuando los visigodos se pusieron en mayor contacto con el mundo latino hispano, el latín vulgar de la región era bastante unitario, pues ya había asimilado la mayoría de las lenguas de sustrato; aunque, en todo sitio, comenzaban a asomar particularidades locales de cada lugar conquistado. Por esta época, se encuentran en ciernes ciertas alteraciones y diferencias de pronunciación, morfosintácticas y léxicosemánticas como preparación a las variedades iberorromances.

Los visigodos, en sus correrías de este a oeste, desde la Dacia, actual Rumanía, fueron expulsados, en 270+, por el emperador Aureliano. En 332+, helos como foederati del Imperio Romano en defensa de la frontera norte del Danubio. En 375+, tiene lugar la invasión de los hunos capitaneados por Atila, quien empuja a los visigodos y otros pueblos hacia la parte occidental del Imperium Romanum, donde llegaron haciendo gala de toda clase de "fechorías y diabluras". El punto culminante, comandados por Alarico, fue el saqueo de Roma del 410; un año después, llegan los visigodos a la Hispania Tarraconensis. Luego, continuaron su marcha hacia la Aquitania Secunda (suroeste de Francia). Permanecen en la Gallia 100 años, por lo cual, en Tolosa, fundan su capital; mas, al ser expulsados por los francos, la más poderosa e importante tribu germánica, se abalanzan sobre la Península Ibérica, por el 415, siempre bajo las órdenes de Alarico; en Toledo, constituyen su nueva capital, capital hasta la conquista peninsular de los moros, en 711, cuando desaparece, sin dejar rastro alguno, el rey don Rodrigo, caído en la batalla junto al río Guadalete.

Unos 150.000 visigodos traspasan la frontera montañosa de los Pirineos entre Gallia e Hispania. Aquí se topan con un número mucho mayor de hispanorromanos (unos 9.000.000); pero como los visigodos iban en plan aguerrido de conquista, los primeros son sometidos política y militarmente aunque no cultural ni lingüísticamente, pues los visigodos aceptaron lo latino, ya casi en vías hacia lo románico.

La asimilación a la cultura de los hispani-romani no les resultó difícil: dadas sus correrías por gran parte del Imperio Romano, llegaron a la Península Ibérica semirromanizados, semilatinizados y semicristianizados, lo cual significa que al menos balbuceaban el latín. No profesaban el cristianismo romano sino que estaban más bien teñidos de la profesión "herética" proclamada por Arrio, quien negaba la divinidad de Jesucristo.

Con la Abjuración de Recaredo del arrianismo al cristianismo romano (III Concilio de Toledo, 589), la asimilación fue casi completa, incluso contra las pretensiones de Leovigildo, último representante del nacionalismo visigodo, pues su hermano, el rey, acepta el cristianismo romano gracias a san Leandro, como otrora lo había hecho Clodoveo en Galia. Acto seguido, son permitidos los matrimonios entre hispanorromanos y visigodas, o viceversa.

\section{Asentamiento y núcleo de población de los visigodos}

Esta tribu germánica se situó en los siguientes lugares: Meseta Castellana: norte de Palencia y de Burgos, Soria, La Alcarria, Madrid, Segovia y Toledo, capital del reino.

Los diferentes núcleos de población, en contraposición con otras etnias, principalmente con la latina: Romanos, Romanillos, Romanones, se extraen de distintas denominaciones 
toponímicas como: Gudillos, Godos, La Goda, Godones, Godojos, Gudiño, Campi Gothorum $>$ (Campo)toro, Villa Gothorum > Villatoro y, según algunos, el nombre de Cataluña > Gotolaunia.

\section{Estado idiomático de Hispania visigótica}

Antes de la invasión árabe en Hispania, ésta hacía alarde de tres idiomas: el latín culto medieval, el latinum circa romancium y el romance visigótico.

El latín culto medieval era usado por unos pocos letrados, entre los que se encuentra san Isidoro de Sevilla. De entre los distintos reinos germánicos, el latín de la época visigótica era mucho mejor que el latín merovingio de los francos y el latín de los longobardos y ostrogodos de Italia. Tal latín era normalmente escrito para asuntos administrativos y judiciales.

El latinum circa romancium era empleado por personas con menos pretensiones culturales, como ciertos notarios. Era un latín bastante romanceado, o un romance bastante latinizado, que concuerda, en muchos aspectos, con el leonés occidental, el gallegoportugués y el mozárabe del centro y del sur, prontos a surgir.

El romance visigótico constituía el idioma de la gente sin formación escolar alguna: un latín vulgar semirromanizado con elementos del superestrato propio del germánico visigótico; primero, global para las variedades iberorrománicas. Tal latín vulgar se hallaba en vías de transformación hacia el neolatín y estaba provisto de unos 125 préstamos visigóticos, algunos aún existentes.

El romance visigótico logra mantenerse controlado por la corte de Toledo, como luego, la misma corte logrará controlar el naciente romance procedente de la norteña Castilla. Su mayor diferenciación es más bien consecuencia de la llegada y estadía de los árabes en suelo peninsular.

En el período objeto de esta presentación, a pesar de que los visigodos constituían la clase dominante, triunfó el latín como lengua de cultura y el romance coloquial por el recuerdo perenne que suscitaba Roma y el prestigio de su cultura e idioma, a lo cual iba aunado el cristianismo romano, causas del triunfo de lo latino sobre lo germánico. Vale la pena esbozar la figura de San Isidoro de Sevilla a partir de la siguiente cita extraída del libro Copistas y filólogos:

\footnotetext{
...el florecimiento de la cultura visigótica en España no tuvo lugar hasta fines del siglo VI y principios del VII. Este resurgimiento debe su lugar en la historia de la cultura clásica principalmente a la obra de su más notable escritor, Isidoro de Sevilla (c. 570-636). Gracias a la extraordinariamente rápida difusión de su obra por toda Europa, hecho sorprendente en la época precarolingia, Isidoro quedó rápidamente consolidado como uno de los agentes más influyentes en la transmisión y elucidación de la sabiduría antigua. Sus "Etimologías" fueron al mismo tiempo el último producto de la tradición enciclopédica romana y el punto de arranque de muchas compilaciones medievales...
}

\section{Préstamos del visigodo al español}

Dado el dominio de los visigodos en Hispania, se podrían esperar muchos préstamos. ¡En realidad, no!: apenas unos $\mathbf{1 2 5}$ lograron calar en el romance, debido a las siguientes razones: 
1. Los visigodos fueron relativamente romanizados, cristianizados y latinizados con facilidad.

2. Asesinatos, luchas fratricidas, incluso, regicidios, empañaron, sobremanera, esta época.

3. La cultura visigoda apenas estaría comenzando a madurar, cuando cayeron los árabes y desapareció el reino, sin que pudiera crecer ni arraigar, en la población hispanorromana, lo poco que les restaba de autóctono.

\section{Préstamos antroponímicos}

Los nombres visigodos, siendo de origen germánico, hacen referencia a la fama, el valor y la guerra y están conformados, igualmente, por un sintagma bitemático (conformado por dos partes, como ya manifesté): Alfonso, Ramiro, Álvaro, Fernando, Gonzalo, Adolfo, Elvira.

Los préstamos que más me llaman la atención se dan en la antroponimia, en donde destacan ciertos nombres de persona y algunos apellidos, derivados de éstos, de mucho uso, incluso, en la actualidad. Por ejemplo, el nombre de Rodrigo debe su enorme difusión al último rey visigodo caído en 711, en la batalla junto al río Guadalete. Su forma hipocorística es $R u y=$ Roy $>$ Ruiz. El paso de Rodrigo a Rodríguez se da de la siguiente manera:

Los sufijos $-z$, -ez, en español y $-s-e s$, en portugués, son de origen prerromano. Su propagación y consolidación se debe a numerosos genitivos latinizados en -rici > -riz.

Ejemplos: ger. hruoriks < hruot, fama, gloria, y riks (cf. lat. rex) = señor rico, poderoso, rico en gloria, poderoso por su fama, príncipe glorioso: rodericus, gen. roderici $>$ Rodríguez. Por ejemplo, Petrus Roderici significa Pedro Rodríguez, esto es, filius Roderici, hijo de Rodrigo; Antonius Fridenandici, Antonio, hijo de Fernando > Fernández o Hernández.

Walter $<$ walten, mandar, gobernar, y heer, ejército $>$ walthari, las huestes del poder, $>$ witerici $>$ guitiriz $=$ Gutiérrez, o sea, hijo de Walter.

Álvaro $=$ protección de todos: $<$ alwars $<$ all (al. all, todo; alle, todos.) y warja, defensa, protección.

Fernando = el atrevido por la paz: < firthu (al. Friede, paz) y nands, atrevido.

Alberto $<$ Adalberto $=$ noble brillante $:<$ adal (al. adel, noble) y berth (como en Berta), brillant (ingl. bright).

Los antropónimos anteriores fueron muy usados hasta el siglo XII, cuando se vuelve a los nombres en latín debido, de seguro, a la restitución por influencia de Cluny.

\section{Sufijos en -engo}

Estos sufijos son muy pocos y sólo se emplean ocasionalmente. Ellos son: abadengo, abolengo, realengo y uno que otro más.

\section{Sustantivos y verbos}

Existen otros préstamos relacionados con léxico relativo al valor emocional, a lo jurídico, la casa, el pastoreo-agricultura y los nombres de animales. 
Coloco los siguientes nombres por categorías gramaticales y en orden alfabético:

Sustantivos: ayo (-a), brasa, brote, casta, espía, esquila, gana, ganso, gavilán, guardia, guardián, parra, ropa, sala, sayón, notificador, ministro de justicia, vástago.

Adjetivos: (a) marrido, con el significado de apenado, quizás, provenga a través del provenzal, de acuerdo con E. Gamilscheg.

Verbos: agasajar, ajugar, arengar, ataviar, desmayar, que se deriva del antiguo francés esmaiier, con el significado de perturbar; guiar, sacar, triscar, vástago.

\section{Conclusión: lo bueno y lo malo de la época visigótica}

Además de la presencia providencial de San Isidoro de Sevilla, quien se constituye en un enclave de lo "clásico", en la época visigótica, se realiza una fusión de lo germánico con lo latino románico, elemento predominante, y la aparición del futuro espíritu cristiano-español, en contra de lo musulmán, la existencia de un estado nacional, en contra de lo árabe y en contra de un imperio universal con un poder absoluto; el rey, aunque sagrado y autocrático, es elegido por una asamblea de hombres libres, aunque con intereses personales que le confieren un poder limitado; y la propiedad individual de la tierra genera un carácter sedentario, aunque feudal, contra las antiguas correrías desde Rumanía.

La completa unidad se manifiesta en lo gótico por romani $>$ hispani, en una unidad jurídica: Lex visigothorum (leyes y costumbres germánicas > Fuero Juzgo), en una unidad política: el reino; en una unidad religiosa: el cristianismo romano y en una unidad idiomática tripartida girando en torno al latín.

Sin embargo, ya el reino visigodo llevaba en ciernes ciertos defectos, que, a la postre darían con él por tierra: rivalidades dinásticas con guerras intestinas inherentes y regicidios, por culpa de intereses personales de la nobleza: toda una preparación para el desastre de Guadalete del 711.

Durante la Hispania visigótica, comienza a eclipsarse el mundo latino y comienza a aparecer una especie de espíritu nacional, del cual se hará abanderada la futura Castilla. Dicha época fue la más culta de todos los anteriores reinos germánicos, pues hay una mayor cantidad y mejor calidad de escritos en los mismos centros de cultura de la época romana, a la que se debe añadir la capital; además, Hispania comienza a sentir el ser de lo nacional, que, posteriormente, no le será muy beneficioso. En el campo linguíístico, perdurarán pocos visigotismos, pues los visigodos son amalgamados por la cultura latina con mayor prestigio, aunque sobre los hombros de la Iglesia de Roma.

\section{Bibliografía}

Arcelus Ulibarrena, Juana Mary. 1977. Introducción a la filología española. Firenze: Valmartina Editore.

Bal Willy. 1966. Introduction aux études de linguistique romane, avec considération spéciale de la linguistique française. Paris: Didier. 
Camproux, Charles. 1980. Las lenguas románicas. Barcelona: oikos-tau, s. a. - ediciones.

Cano Aguilar, Rafael. 1992. El español a través de los tiempos. Madrid: ARCO/LIBRO, S.A.

Entwistle, W. J. 1969. The Spanish Language. London: Faber and Faber Limited.

Elcock, W. D. 1960. The Romance Languages. London: Faber and Faber Limited.

Gamillscheg, E. 1967. “Germanismos”. En: Enciclopedia Lingüística Hispana. Tomo II: Elementos constitutivos y Fuentes. Madrid: Consejo Superior de Investigaciones Científicas.

García Moreno, Luis A. 1988. España en la Edad Antigua. Hispania romana y visigoda. Madrid: Ediciones ANAYA, S. A.

Habel E., Gröbel F. 1989. Mittellateinisches Glossar. Paderborn: Ferdinand Schöningh.

Lleal Galceran, Coloma. 1990. La formación de las lenguas romances peninsulares. Barcelona: Editorial Barcanova, S. A.

Lamer, Hans y Paul Kroh. 1989. Wörterbuch der Antike. Stuttgart: Alfred Kröner Verlag.

Lapesa, Rafael. 1980. Historia de la lengua española. Madrid: Editorial Gredos, S. A.

Marín, Diego. 1969. La civilización española. New York: Holt Rinehart and Winston.

Menéndez Pidal, Ramón. 1982. Manual de gramática histórica española. Madrid: EspasaCalpe, S. A.

Lüdtke, Helmut. 1974. Historia del léxico románico. Madrid: Editorial Gredos, S. A.

Obediente Sosa, Enrique. 2000. Biografía de una lengua. Nacimiento, desarrollo, expansión del español. Cartago: Libro universitario regional.

Penny, Ralph. 1993. Gramática histórica del español. Barcelona: Editorial Ariel, S. A.

Priebsch, R.; Collinson, W. E. 1968. The german language. London: Faber \& Faber Limited.

Reynolds, Leighton D. y Nigel G. Wilson. 1986. Copistas y filólogos. Madrid: Editorial Gredos, S. A.

Rat, Maurice. 1965. Aide-mémoire de LATIN. Paris: Fernand Nathan.

Segura Munguía, Santiago. 1985. Diccionario etimológico latino-español. Madrid: Ediciones generales ANAYA. 
Tacitus, Cornelius. 1998. Germania. Lateinisch-Deutsch. Düsseldorf: Artemis \& Winkler Verlag.

Tagliavini, Carlo. 1981. Orígenes de las lenguas neolatinas. México: Fondo de Cultura Económica.

Vidos, B. E. 1968. Handbuch der romanischen Sprachwissenschaft. München: Max Hueber Verlag.

Wartburg von, Walter. Evolution et structure de la langue française.

Wolf, Philippe. 1971. Origen de las lenguas occidentales, 100-1500 d.C. Madrid: Ediciones Guadarrama, S. A. 